\title{
Conflicting philosophies of inclusion: the contestation of knowledge in
}

\section{widening participation}

Yanina Sheeran ${ }^{a}$, B. J. Brown ${ }^{b}$ and Sally Baker *

${ }^{\mathrm{a}}$ Park Lane College, Keighley, UK; ${ }^{\mathrm{b}}$ De Montfort University, UK; ${ }^{\mathrm{c}}$ University of Wales, Bangor, UK

London Review of Education 5, (3): 249-263, 2007.

\begin{abstract}
This paper explores the conflicting philosophies within the widening participation debate. Two categories of inclusive educators are identified, 'meritocrats' and 'democrats'. Among the democratic educators, a subgroup, 'transformative' educators, exists, which seeks to invoke changes in society and the education system. The positions taken by some of these authors are weakened by their neglect of sociological theory. For the debate to progress and for inclusion to be successful, a renewed understanding of sociological theory is needed. This will help those contributing to the debate to grasp fully the political and economic constraints on students and institutions that have limited inclusion.
\end{abstract}

\section{Introduction}

Concerns that access to higher education is inequitable have been raised since the establishment of the first universities. The reader is referred to Kettley (2007) for an exploration of the origins and history of these concerns, widening participation research and how this research has been influenced by policy.

Despite the substantial expansion of the UK higher education sector during the early and mid-1990s, university students remained stubbornly middle class, despite growing concern by government to create a more socially representative university sector. The policy impetus was evident in publications such as the report by the National Committee of Inquiry into Higher Education (The Dearing Report) (1997) and the Department for Education and Employment publication The Learning Age (1998). 
The election of New Labour in 1997 made the case for social inclusion ever more urgent, such that policy-makers are concerned to remove barriers to citizens' social and economic participation. In parallel with this, the UK Government's drive to increase the proportion of people undertaking higher education, the so-called 'widening participation' policy, began in earnest in 1998 with the publication of From Elitism to Inclusion by the Committee of Vice-Chancellors and Principals (1998), the organisation representing the heads of UK universities. Initiatives such as Aim Higher (in England) and Reaching Higher, Reaching Wider (in Wales) were launched to encourage school pupils from cohorts where higher education was not usually an aspiration.

In this paper, the politico-educational discourse of 'inclusion' in relation to widening participation in the higher education system in England and Wales is examined. Approaches to widening participation as a policy and the ways in which researchers have analysed the impact of widening participation are critiqued. There are often close links between policy and research in this field. Some researchers and the notions promoted through their research are clearly influential among policy-makers. For example, the notion that widening participation initiatives are limited by 'barriers' facing students because institutions are still not trying hard enough (Baker et al., 2006a) has gained near-universal credence amongst ministers and government advisers. Researchers and commentators on the issue of widening participation are amongst the most eager of social scientists for their work to inform policy, so this critique embraces both research and policy itself.

Since devolution there have been different arrangements for higher education in England, Scotland and Wales with differently inflected widening participation debates, yet throughout the UK, a similar sequence of developments in widening access to higher education has unfolded. Whilst we concentrate in this article on the English and Welsh experience, the comments have a broader resonance in an increasingly global higher education marketplace. 
'inclusive', 'democratic' or 'mass' higher education system against an older tradition of 'elitism', where a much narrower segment of the population was educated by a smaller number of more selective institutions (Newby, 2004; Thomas, 2005). The desired impact of widening and democratising access to higher education is rendered all the more urgent because of changes in the way that economies in the developed world are managed. The authors contend that the UK New Labour Government's initiatives regarding widening participation serve the neoliberal economy.

Writers, researchers and policy advisers with very different positions on inclusion in higher education from New Labour have colonised the expanding number of widening participation research and policy-making opportunities. The 'philosophies of inclusion', including the assumptions and political commitments to which contributors subscribe, are frequently not explicit. Instead, the political project of this literature is more subtle, and is visible through the kinds of experiences the authors foreground and the kinds of changes they urge upon institutions themselves (Baker et al., 2006a). Some writers, such as Reay and colleagues (2001a, b), have sought to understand the social precursors of successful participation in higher education in terms of Pierre Bourdieu's cultural sociology. Others however, for example Bowl $(2000,2001,2003)$ and Bamber and Tett (2001), appear to have often developed their arguments largely independently of the tradition of critical sociological enquiry. This has resulted in some work producing a curious myopia where sociological questions are concerned. Within these writings on inclusion there is a variety of theoretically naive, inconsistent, competing and sometimes contradictory voices. This is particularly so in the context of recommending desired ends and outcomes for the higher education system.

Two different thrusts are identified within the inclusionist critique of traditional higher education: a reformist but essentially conservative meritocratic one, seeking the solution in opening up the experience to more young people who are believed to be 'suitable'; and the critique of this from a position of socially inclusive education, seeking to provide the experience of higher education to more people, irrespective of what has traditionally been called 'ability'. Within this latter inclusive line of reasoning, two broad positions differing fundamentally from each other can be identified. Firstly 
there is the 'economistic' position of New Labour, where higher education is seen as desirable because it results in a more economically able workforce. (Tony Blair is alleged to have said that universities are the 'coalmines of the 21st century' [Lawson, 2006, p. 14]). Secondly, there is the 'transformative learning' position of 'critical educators', who see education as an essentially emancipatory or transformative experience. In this view, the policy of attempting to give the UK workforce more qualifications can be subverted or mitigated to substitute a range of more liberatory educational experiences for socially marginalised people and to democratise universities.

\section{Competing philosophies of inclusion}

Attaining policy objectives in the area of widening participation is complicated by different philosophies regarding the purpose of higher education and who should have access to it. After 1997, it was possible to see divisions in philosophies of widening participation. Not all institutions or individuals meant the same thing by widening participation and considerable disagreements began to evolve as to how best to achieve it. Here an attempt is made to analyse some of the different voices in the debate. To begin, the distinction between elitist and democratic visions of participation is considered.

\section{The traditional elitism of higher education}

The Higher Education Funding Council for England (HEFCE) (2005) published an analysis of participation rates among young people (18-30) in higher education in the UK, covering the years 1994-2000. Despite the substantial efforts that had been made to widen participation, the analysis showed that the participation rate had changed very little (27\% for the 1994 cohort, $29 \%$ for the 2000 cohort), remaining stubbornly below government targets. Most worryingly, the research showed that the $20 \%$ of young people living in the most advantaged areas were five to six times more likely to enter higher education than the $20 \%$ of young people living in the least advantaged areas. 
The stark conclusions of the HEFCE (2005) report caused enormous concern and much questioning as to why widening participation had not been as successful as desired, despite the efforts of so many. The early twenty-first century saw elitism mentioned as a concept to account for the failure of high numbers of students from lower socio-economic groups to access university places (James, 2000; Universities and Colleges Admissions Service, 2002); or for the reasons why some institutions taking larger proportions of non-traditional students, such as Bolton, South Bank and East London Universities, lost over a quarter of their students through drop-out (Millar \& Griffiths, 2007). At their crudest, the charges of elitism place the blame for failure on a consciously discriminatory attitude on the part of tutors. This may well be a factor, despite the fact that research at the University of Cambridge, for example, shows that non-traditional applicants are accepted in roughly proportionate numbers compared to the number of applicants (Charter, 2000; Crace, 2005). The notorious case of Laura Spence, a comprehensive school pupil who was refused admission to study medicine at the University of Oxford despite her outstanding academic record, and similar subsequent cases involving three state school pupils applying to Trinity College Cambridge, eventually suggested that the problem was not necessarily prejudice, but the overwhelmingly large numbers of extremely well-qualified applicants for relatively few places (Hodges, 2000; Cassidy, 2003). Yet other influences result in institutions gaining financially from recruiting students from disadvantaged areas, which some commentators maintain is pushing admissions decisions in the opposite direction (Henry, 2006).

Other explanations see more subtle institutional prejudice at work; for example that the ethos of universities creates a 'not for the likes of me' attitude and results in relatively few applications from working-class students. Sometimes an alien ethos or 'institutional habitus' (Reay et al., 2001a) is also held to be responsible for the high drop-out rate of non-traditional students. 


\section{The challenge to traditional elitism}

From amongst the many advocates of widening participation in higher education, we can identify two broad camps who seek to challenge and change what they consider to be the traditional elitism of the university sector. There are the 'meritocrats' (often termed 'elitist' by their detractors) and the 'democrats', or supporters of mass higher education (Newby, 2004).

\section{The meritocratic model of inclusion}

The meritocrats are not elitists in the sense of necessarily believing in hereditary ability and the right to rule of a small group. In the main, the meritocrats suggest that university should be open to all those of a certain perceived ability, irrespective of their social background. Proponents of this model of widening participation include Peter Lampl, who established the Sutton Trust to 'provide educational opportunities for young people from non-privileged backgrounds' (www.suttontrust.com). At a national level, meritocratic ideals prevail in the establishment in the UK of the proposed database of pupils performing strongly in Key Stage 2 tests as a way of enabling the elite universities to recruit their quota of non-traditional students (Halpin, 2006).

In its most extreme manifestation, the meritocratic view is espoused by New Right theorists such as Peter Saunders (2005) and Charles Murray (1999). They suggest that we already live in a meritocratic society, in which anyone with talent who works hard can access university and that those now making up the 'underclass' are in that position because of their innate lack of ability. The emphasis on the role of heredity and endogenous patterns of marriage and procreation has made their views unacceptable to many.

The Conservative Party's 2005 election manifesto made clear that they would adopt meritocratic policies, cutting the number of university places, but providing good financial support for students from low-income families. David Cameron's idea of only allowing a fixed quota of top A level grades each year illustrates the meritocratic 
position (Sylvester, 2005). The recent call from the National Association of Head Teachers to make A levels more difficult (Clare, 2005), and the movement of some UK independent schools to the 'harder' International Baccalaureate, indicate that they wish to position their students within a perceived meritocratic system.

Oxbridge and the Russell Group universities tend towards a meritocratic position that might be characterised as the 'rough diamond' approach to recruitment, concentrating on seeking out the brightest students from disadvantaged groups, giving them taster experiences and preparation to equalise their chances of entry.

The advocates of a meritocratic model of education such as philanthropist Peter Lampl (Lampl, 2007), and the former Chief Inspector of Schools, who now holds a Chair at the University of Buckingham, Chris Woodhead (Woodhead, 2007), are keen on equality of opportunity and fair access, but the resulting patterns of participation are 'exclusive' in the literal meaning of the term. Only the very able are included. The emphasis is on identifying only the 'best of the bunch', however large or capable the whole bunch might be. Thus the meritocratic model is more about 'fair access' than widening participation per se. There is, furthermore, a fear on the part of some meritocrats that 'letting in' non-traditional students, by lowering traditional entry requirements or altering traditional provision, is undermining what was once considered to be the best university system in the world (Randall, 2005).

\section{Democratic models of inclusion}

Democratic educators, such as Howard Newby and many writers on widening access, believe that many of the differences in the educational performance of individuals are the product of social inequalities rather than innate differences in talent. They are truly egalitarian, rather than believing in students having equal opportunity to be unequal as the meritocrats do. This democratic school of thought encompasses all those researchers who espouse inclusion. There are, however, significant differences of emphasis about how this is to be achieved and the kind of education that should be offered. 
In the next section, these and other differences and contradictions are further explored, through the construction of two competing models of inclusion.

The economistic model of inclusion. The economistic model of inclusion might be said to owe its origins at least in part to former British Prime Minister James Callaghan's Great Education Debate of 1976, which, together with the subsequent 'New Vocationalism' of the 1980s, heralded an era of instrumentalism in education. The New Labour rationale for increasing participation to $50 \%$ of the population between 18 and 30 years of age by 2010 (using this to increase participation for those groups currently under-represented, especially from low-income families and low-participation areas), is that an advanced industrial nation will capitalise on a growing proportion of educated and able people.

The New Labour policy of 'widening participation' in higher education was also based on a commitment to social justice and social inclusion (Department for Education and Employment, 1998). This concern was fuelled by fears that social order and cohesion were being threatened by a socially excluded underclass. Since such a policy results from enlightened self-interest characteristic of communitarianism and Third Way politics, it can also be characterised as an economically driven initiative. 'Education, Education, Education' was one of Tony Blair's key election slogans in 1997. Blair saw higher education as a way of increasing health, preventing welfare dependency and social unrest and the consequent tax burden for welfare and policing, as we have argued elsewhere (Baker et al., 2006b).

Newby (2004) set out the new vision of what, in piecemeal fashion, was already beginning to happen. The reforming economistic democratic or mass participation model of inclusion required the universities to alter their curriculum, becoming more user-friendly to non-traditional students in terms of both content and modes of delivery. New part-time and sub-degree vocational courses like foundation degrees would accept nontraditional students with lower or no formal qualifications. Anyone who wanted to and who could benefit from some form of university education should 
be entitled to it. Newby's view of 'Lifelong Learning Networks' embraced both further education and higher education (Higher Education Funding Council for England, 2004).

However, parity of esteem between vocational and academic courses and between different social groups has not occurred. Instead, we have begun to see the stratification of the sector in terms of the curricula offered as well as social composition (Reay et al., 2005). Many educators are critical of the instrumental purpose of the economistic model and have another vision for higher education. For example, Edwards et al. (2001) draw on critical social policy studies and post-structuralist philosophy to mount a critique of inclusion in terms of maintaining the rights of individuals to choose their own exclusions, identities and differences. This is part of a radical challenge that has come from critical educators with a profoundly different political vision of university education. They may be characterised as 'transformative educators', hoping to mitigate what they see as the worst effects of economistic endeavours of the 1980s and New Labour and transform society through a new form of critical education.

The transformative model of inclusion. Many transformative educators can be found among the ranks of those who valued liberal adult education prior to the 1990s (Blyth, 1983; Hall, 1985). They believe in fully funded higher education for disadvantaged groups and constitute a broad 'liberal educational consensus', uneasy with the economism of current government policy. Many are profoundly critical of New Labour education policies, believing that there are fundamental flaws in the capitalist system and that the education system generated by the prevailing politico-economic environment is systematically oppressive. This underlies the commitment of many transformative educators to equal opportunities in respect of gender, ethnicity, sexual orientation and disability and the belief that the education system can be used to engineer a better world.

Transformative educators, that is, 'critical educators', see lower socio-economic groups and non-traditional students as victims of an oppressive economic system and 
as representatives of cultures undervalued and marginalised by formal educational systems. There is a commitment to the empowerment and capacity-building of marginalised groups. Transformative learning is assumed to lead to particular transformative action-a new social and economic order of social justice.

The pedagogic discourse of many transformative educators draws on educational theory generated in the context of adult learning. It draws on the concept of transformative learning associated with the work of Mezirow $(1991,1995)$ which focuses on the cognitive transformations that adult learners can be encouraged to experience as part of their return to study. Mezirow's seemingly 'apolitical' theory of transformative learning is used by critical educators as the pedagogical legitimation of education for an alternative socio-politics and an alternative way of understanding the research process in which many of them are also engaged (Kreber, 2005; Schnelker, 2006).

Mezirow's psycho-social model has been politicised through the use of the radical work of educators like Freire (1985), while transformative educators' vision of capacity-building and social transformation is also indebted to the work of Habermas (1990). The term 'critical pedagogy' is preferred by transformative educators, drawing upon the generative work again of Freire, but also Giroux (1997). Critical educators believe that there is an inevitable link between transformative learning and the transformation of society.

Even so, there are some acknowledged shortcomings, many of which centre upon the implicit model of the learner contained in this account of education:

The central error in all this ... is assuming that self-direction is a natural trait of adults and that the learning habits and critical capacities which underpin such learning will develop without the guidance and support of teachers. (Hyland \& Merrill, 2003, p. 139)

Transformative educators therefore have an active role to play in providing students with an awareness of politically alternative ways of thinking and behaving that will 
enable them to be critics of contemporary society. The transformative educator's approach in relation to the higher education context is neatly summarised by Jane Thompson:

The challenge presented by widening participation in higher education ... is not in our view about 'helping' the socially excluded; or squeezing more non-traditional students into increasingly overcrowded lecture theatres ... rather it is about developing a sustained critique of current rhetoric, developing a distinctive social theory of knowledge derived from a politically committed analysis and theory of power which leads to a form of pedagogy that is concerned to democratize knowledge and learning, in ways that redefine the very parameters of what counts as higher education. (Thompson, 2000, p. 10)

\section{Philosophies of inclusion and higher education policy}

The way in which the various strands of the inclusionist discourse manifest themselves can be seen in widening participation strategy documents such as those published by the Universities UK and the work of researchers committed to widening participation.

Social Class and Participation in HE-From Elitism to Inclusion 2 (Universities UK, 2002), a follow-up report succeeding From Elitism to Inclusion (Committee of Vice-Chancellors and Principals, 1998), was distinctly different from the original, as researchers with different agendas began to make their contribution. The 2002 report was committed to disseminating good practice in widening access and had solicited the contributions of scholars more explicitly committed to the changing role of universities in UK society (Quinn, 2005b). The New Labour Government was still firmly committed to widening access in higher education and by the beginning of the twenty-first century, research had begun to proliferate on the experiences of non-traditional students. A substantial amount of qualitative work was carried out, examining the 'barriers' preventing students from these social groups from 'succeeding' in higher education (Archer \& Hutchings, 2000; Bowl, 2000, 2001, 2003). 
In these studies, the problem is conceived as stemming from the higher education institutions themselves. The putative barriers seem not dissimilar to those identified by meritocrats, such as funding, unfamiliarity and lack of parental knowledge. But the blame for this is placed at the doors of the universities. It is seen as the universities' job to change so as to become more attractive to non-traditional students. Any attempt to identify difficulties intrinsic to the students, such as the desirability of their acquiring knowledge or skills, is seen as 'pathologising' non-traditional students, or as seeing them in terms of a 'deficit' model (Bowl, 2004; Quinn, 2005a; Thomas, 2005). Reay et al. (2001a, b) and Bowl (2001), key writers in the widening participation field, suggest that universities, as a result of their white middle-class ethos or 'institutional habitus', are still unwelcoming places for disadvantaged students.

Quinn (2003, 2005a, b) and Quinn et al. (2005a, b) extend the argument by stating that there needs to be a radical transformation in the view of what is involved in a university education. These authors see most existing widening participation initiatives as based on a 'deficit model' of students. They maintain that non-traditional students have knowledge, experiences and perspectives that will make a vital contribution to a university education.

Thomas (2005) and Jones \& Thomas (2005) identify the apparent gap between government policy and the fact that widening participation initiatives have failed to make substantive changes to academic life so as to privilege hitherto disadvantaged groups of students. This is seen to result from a reluctance by many in the higher education sector to embrace the necessary change to achieve real widening participation. Thomas identifies two different approaches to widening participation. Firstly, she posits an 'academic' model (the 'meritocratic' one in this paper), which is based on a deficit view of non-traditional students' cultures, ignores structural obstacles to access and sees no basis for institutional change. Secondly, she identifies a 'utilitarian' model (the 'economistic' one here), which is, in reality, tailored to meet the requirements of the labour market, although rhetoric conflates it with the needs of under-represented groups. Thomas maintains that this latter model is based on the needs of the economy and mainly ignores the wider benefits of higher 
education for non-traditional students. In this view, these wider benefits have been increasingly monopolised by traditional students in the more prestigious universities. She suggests that the role of university tutors should be to facilitate transformative learning, that academic ability and knowledge is only one sort of talent and that working-class students with different abilities and interests are excluded because of the special regard in which 'middle-class' knowledge is held (Thomas, 2005).

Thomas is critical of measures such as the 2004 Higher Education Act and the establishment of OFFA, the Office for Fair Access. She states that 'OFFA offered the chance to create a mechanism to promote a transformed higher education system, but this opportunity has been squandered'. She argues that under OFFA rules, change is emphasised for potential students, not institutions, and this reinforces the academic (meritocratic) model of widening participation. She maintains that the 'Act is largely underpinned by a traditional and elitist model of widening participation' (Thomas, 2005).

Thomas (2005) describes her vision of a 'transformative' system of education, which is rather different from the prevailing view of widening participation. A transformative approach focuses on the broader interests of under-represented groups and suggests that higher education should be gauged to meet needs of these groups. This will demand far-reaching structural change-instead of being viewed as deficient, non-traditional students will be able to inform the change process. Thomas is insistent that all institutional activities should be underpinned and informed by a positive view of diversity and this requires them to review their processes of knowledge production and transfer and their internal structures of powers and decision-making.

\section{Sociology and the critique of inclusionist discourse}

Much of the popular widening participation debate takes place without much reference to the rich tradition of critical sociological writing on the subject of inequalities in education. Yet sociology has much to contribute to the philosophical and 
epistemological issues raised by the inclusionist discourse.

Both traditional elitist and meritocratic models of education implicitly draw on a long tradition, from the classical nineteenth-century functionalist sociology of Durkheim to that of the current New Right. Schools and universities try to provide compensatory educational experiences for deprived youngsters, to equip them with some knowledge both of the higher education system and its traditional knowledge systems. Widening participation and inclusion within the meritocratic model are presented as a matter of induction into the academy. However, from the inception of 'compensatory education', there was vehement opposition from democrats to this 'deficit model' of widening participation, because of the implied denigration of non-traditional students' culture. In the beliefs of many transformative educators there are echoes of the arguments rehearsed over three decades previously by Keddie's (1973) contributors. They are also mirrored in the Marxist critique of compensatory education provided by the "new sociology of education' (Young, 1971).

Economistic models of inclusion also owe much to those earlier traditions of sociological thought. From classical functionalist theory (Durkheim, 1893; Parsons, 1951; Bendix \& Lipset, 1966) came the idea that the systems and institutions of a society are interlinked and fulfil one another's 'needs'. In this view the education system must perforce be a means of sorting people into different roles, occupations and towards different apportionments of the society's resources. In these models the existing capitalist system is not under scrutiny.

In contrast, transformative educators owe a debt to Young (1971) regarding their arguments about the nature of academic knowledge. His views regarding the relativism of educational knowledge led to critical educators accepting that knowledge is socially constructed to serve the interests of dominant groups. It is this tradition of thought that has led transformative educators like Thomas (2005) to argue that inclusive higher education must challenge both traditional academic knowledge and the instrumental knowledge that is used to service the economy. 
Hoggart (1957) and Jackson and Marsden (1969) detailed the experience of the working-class grammar school boy in a way which was curiously prescient of the discomfort later described by the informants of Bowl or Thomas. Yet Hoggart and Jackson and Mars-den did this without recommending any dilution of the educational experience acquired in the process. Whilst Thomas (2005) has in common with Hoggart a stress on the importance of the knowledge and insights that non-traditional students bring to their study, she retains no comparable nostalgia for the powerful frames of understanding that education can add to the working-class experience, a theme recently echoed by Young (2005), who has now repudiated his earlier relativist stance towards the nature of academic knowledge.

The rhetoric of empowerment and transformative action clearly indicates that the new inclusive education will generate knowledge for transformative community action. Yet much classic work on the ethnography of young people suggests that rather than being incipient scholars, the youths in question have rather different interests and plans. Willis' (1977) 'lads' who were 'learning to labour' frequently used school as an opportunity to 'muck about'. Cohen and Robins' (1979) 'Knuckle Sandwich' youths and Williamson's (2004) 'Milltown Boys' had priorities other than education. In contemporary research, the motives and perceptions of those involved in access to further education and higher education are ambivalent. Some participants see educational institutions as marginalising them (McFadden, 1995), and others see themselves as making strategic choices given the vagaries of the benefits system and the flexible, casualised labour markets one has to contend with as an unqualified person (Warmington, 2003). The gendered performance of identity draws some potential students away from an educational path which they see to be feminised towards activities which reflect an archetypal masculinity (Nayak, 2003). Structuralist analysis suggests that these perceptions and performances may misrepresent the reality of oppression and exploitation experienced by disadvantaged social groups. Interestingly, Slack (2003) explored how an initiative targeting 13-14 year-olds with the aim of raising aspirations regarding post-compulsory education failed to account for the cultural and social background of the students and was actually initiated and imposed from the perspective of an adult with a different class and habitus. In both 
classical and contemporary sociological literature there are important clues as to why inequalities in educational and occupational opportunities appear to persist despite the higher numbers manifestly attending university.

Yet the writing of many proponents in contemporary inclusionist discourse appears uninformed by this tradition. There are exceptions-some researchers are sociologists and do draw heavily on sociological theorists. Baker and colleagues (2006a) described how much widening participation research left any debt to sociological influences largely unexplored or unacknowledged. The gloss is a vague 'empowerment' and 'enabling' philosophy.

These modern variations of the much longer history of widening access discourse seem to be strangely eviscerated of sociological content and are instead pitched at a social-psychological level where the barriers to access are often seen as little more than prejudices on the part of university staff. The impression created is of findings and recommendations based instead on 'educational' theory, 'common sense' and empirical research. This research seeks to inform policy—much of it has indeed been influential and here we can see yet again a sort of sociological naivety. Gorard and colleagues (2006), in their extensive review of a sizeable body of widening participation research, levelled criticisms at some of this research, but did not comment on the absence of sociological theory from so much of it. Significantly, Kettley (2007) pleads for a more 'holistic' research agenda in widening participation research and also observes that certain common research practices in the field 'have inhibited the emergence of productive accounts of participation, which expand the explanatory resources of sociology' (p. 343).

Instead of addressing issues relating to social structure and system, or the differing sets of values and identities which people assume in late modernity, something else is happening in much of the widening participation discourse. The academy itself is becoming a site for the contestation of knowledge at a most fundamental level-a three-way fight between traditional educators, economistic educators and transformative educators. The contest cannot easily be resolved because of the 
difficulty in anchoring the contested ideas in their present form to anything beyond recruitment and assessment processes. Deficit models of widening participation are now being subjected to criticism and the problems of access are being reformulated by government and higher education institutions within the language of inclusion and empowerment. It is a highly denatured version of empowerment compared with Freire's original formulation. It delimits the view of widening participation that can be taken and tends to turn scrutiny inwards, to the curriculum, assessment process and putative attitudes of the staff. Yet these are necessarily limited in terms of how effective they can be against the structural processes of stratification that are theorised in much classical and contemporary sociology.

\section{Conclusion: implications for policy}

Widening participation and its associated discourses of democratisation and transformation are supported by government policy and funding is available primarily for the promotion of institution-level initiatives. However, it is clear that a unitary, official government position cannot easily be defined because these ideas are contested and are shifting over time. The reasons for this lie partly in the competing positions of the educational experts in the field, as we have outlined above. This results in some of the paradoxes and tensions in theory, research and policy. The contradictions between these different positions and confusions in policy mean that the debate and the practice of widening participation have become congested and thus little real progress is likely. Any theory of the wider societal or economic picture has been delimited so that further pressure has been placed on personnel responsible for recruitment, teaching and assessment, with little acknowledgement that much of what they are being asked to do will be beyond their powers.

It is clear that widening participation policy is becoming increasingly divided, firstly between elitists and democrats. Within the elitists, few now cling to the old hereditarian elitism, substituting for it instead a 'new meritocracy'. The language of New Labour has often been that of the democratic position, and the establishment of OFFA and the 2004 Higher Education Bill was perceived by many to have been a victory for the 
democrats. However, there are indications that, in many ways, meritocracy is dominating.

The bursaries offered by universities as part of the 'deal' to permit them to charge top-up fees reveal a meritocratic system in the ascendant at the top end of the sector. Sizeable bursaries are usually offered, particularly by prestigious universities, for academic excellence. By contrast, some new universities only offer the smallest bursaries. Redbrick universities tend to occupy the middle ground. Most institutions have a mixture of allocations-from aid to alleviate poverty, to reward for high attainment. Most also have some money for outreach work with schools and communities that have backgrounds with low participation rates. Most universities offer extra money to students from underrepresented groups. In terms of leading universities' bursaries, 'their funding is aimed at attracting intellect and talent, to ensure they maintain their status in the hierarchy' (McCormack, 2005, p. 4).

To realise the democratic vision, Newby (2004), as Chief Executive of HEFCE, put forward the view that higher education and further education together should provide 'Lifelong Learning Networks' offering a wide range of courses and progression pathways into university-level study. However, the 2005 Foster Report identified mission drift in the work of further education colleges and suggested focusing on their core business of further vocational education and training. The concentration on vocationalism suggests that the economistic model currently predominates, despite the best efforts of the transformative activists. This has been strengthened through the introduction of foundation degrees. Bowl (2004) notes how mature students have been dropped from the higher education agenda.

The goal of transformative action through transformative education is a notion which has underpinned a good deal of scholarship on widening access. Concerns with social justice and the myriad ways in which non-traditional applicants have been held back germinated in this approach well before the 1976 Great Education Debate. To many of those in higher education who can remember the political explorations of class, gender and ethnic inequalities that flourished in academia from the 1960s to the end of the Thatcher years, these ideas have an intuitive appeal. Yet many of the present-day 
incarnations of this approach lack an account of social structure within which to embed their insights. Neither do they sufficiently implicate the political and economic forces which materially constrain the opportunities available to personnel and potential students. It is as if politics were merely a mélange of policy documents and speeches, discrimination was solely about tutors' attitudes, and social mobility was indeed readily achievable via a degree from a post-1992 institution.

It is by looking at how the positions in the widening participation debate have become deadlocked that we can see how it is that an apparently liberatory and democratic initiative can have the opposite results. Some renewed attention to the half-forgotten sociological legacy, which offers the possibility of a new educational experience that is broad ranging, liberal and emancipatory, could ensure that the dominance of a simple economistic model of education and social inclusion is not a foregone conclusion.

\section{Notes on contributors}

Yanina Sheeran is the Access to HE Coordinator at Park Lane College, Keighley. From 2003 to 2005 she was an Excellence Fellow in association with the University of Bradford, working on widening participation research and initiatives.

B. J. Brown is Reader in Healthcare Communication at De Montfort University. He is interested in the nature of philosophical inquiry and has published widely in the fields of healthcare, education and the nature of the research process.

Sally Baker is a Post Doctoral Researcher in the School of Social Sciences, University of Wales, Bangor. She is interested in HE policy, mental health policy and Welsh identity, with particular reference to Bourdieusian and Foucaldian notions and has published on these themes.

\section{References}

Archer, L. \& Hutchings, M. (2000) Bettering yourself? Discourses of risk, cost and benefit in ethnically diverse, young, working-class non-participants' constructions of 
higher education, British Journal of Sociology of Education, 21(4), 555-574.

Baker, S., Brown, B. J. \& Fazey, J. A. (2006a) Individualisation in the widening participation debate, London Review of Education, 4(2), 169-182.

Baker, S., Brown, B. J. \& Fazey, J. A. (2006b) Mental health and higher education: mapping field, consensus and legitimation, Critical Social Policy, 26(1), 31-56.

Bamber, J. \& Tett, L. (2001) Ensuring integrative learning experiences for non-traditional students in higher education, Widening Participation and Lifelong Learning, 3(1).

Bendix, R. \& Lipset, S. M. (Eds) (1966) Class, status and power: social stratification in comparative context (2nd edn) (New York, Basic Books).

Blyth, J. A. (1983) English university adult education 1908-1958. The unique tradition (Manchester, Manchester University Press).

Bowl, M. (2000) Listening to the voices of non-traditional students, Widening Participation and Lifelong Learning, 2(1), 32-40.

Bowl, M. (2001) Experiencing the barriers: non-traditional students entering higher education, Research Papers in Education, 16(2), 141-160.

Bowl, M. (2003) Non-traditional entrants to higher education: 'they talk about people like me' (Stoke-on-Trent, Trentham Books).

Bowl, M. (2004) Frustrated participants: adult learners and higher education aspiration. Available online at:

http://asp2.wlv.ac.uk/webteam/confs/socdiv/soc_div_mbowl.doc (accessed 30 April 2006).

Cassidy, S. (2003, August 15) Cambridge college accused of elitism after rejecting star students, The Independent, p. 1.

Charter, D. (2000, October 16) Cambridge reveals huge disparity in state school intake, The Times, p. 3.

Clare, J. (2005, August 19) Results give four in five a place at university, The Daily Telegraph, p. 17.

Cohen, P. \& Robins, D. (1979) Knuckle sandwich (Harmondsworth, Pelican Books). Committee of Vice-Chancellors and Principals (1998) From elitism to inclusion: good practice in widening access to higher education (London, CVCP).

Crace, J. (2005, October 18) Interview horror-the movie: to demystify the selection 
process, Cambridge University has released its own DVD, The Guardian, p. 10. Department for Education and Employment (1998) The learning age: a renaissance for a new Britain (London, Her Majesty's Stationery Office).

Durkheim, É. (1893) De la division du travail social: étude sur l'organisation des sociétés supérieures [On the division of labour in society: studies of the organisation of advanced societies] (Paris, Alcan).

Edwards, R., Armstrong, P. \& Miller, N. (2001) Include me out: critical readings of social exclusion, social inclusion and lifelong learning, International Journal of Lifelong Education, 50(5), 417-428.

Foster, A. (2005) Realising the potential: a review of the future role of further education colleges (Annesley, DfES).

Freire, P. (1985) The politics of education: culture, power, and liberation (D. Macedo, Trans.) (South Hadley, MA, Bergin).

Giroux, H. A. (1997) Pedagogy and the politics of hope: theory, culture, and schooling (Boulder, CO, Westview Press).

Gorard, S., Smith, E., May, H., Thomas, L., Adnett, N. \& Slack, K. (2006) Review of widening participation research: addressing the barriers to participation in higher education (London, Higher Education Funding Council for England).

Habermas, J. (1990) Moral consciousness and communicative action (C. Lenhardt \& S. Weber Nicholsen, Trans) (Cambridge, Polity Press).

Hall, W. A. (1985) The adult school movement in the twentieth century (Nottingham, University of Nottingham, Department of Adult Education).

Halpin, T. (2006, April 26) Top 5 per cent are to be placed on a national register, The Times, p. 29.

Henry, J. (2006, April 23) 'Disadvantaged' get easier entry to college, The Sunday Telegraph, p. 10.

Higher Education Funding Council for England (2004) Lifelong learning networks (London, HEFCE). Available online at: www.hefce.ac.uk/pubs/circlets/2004/cl12_04/ (accessed 30 March 2006).

Higher Education Funding Council for England (2005) Young participation in higher education (Bristol, HEFCE).

Hodges, L. (2000, June 8) Lies, damned lies-and Laura Spence, The Independent, 
pp. 2-3.

Hoggart, R. (1957) The uses of literacy: aspects of working class life (London, Chatto and Windus).

Hyland, T. \& Merrill, B. (2003) The changing face of further education (London, RoutledgeFalmer).

Jackson, B. \& Marsden, D. (1969) Education and the working classes

(Harmondsworth, Pelican Books).

James, O. (2000, June 15) We must fight elitism in higher education, The Guardian. Available online at http://www.guardian.co.uk/manifesto/article/0,, 332460,00.html (accessed 12 October 2007).

Jones, R. \& Thomas, L. (2005) The 2003 UK Government higher education White Paper: a critical assessment of its implications for the access and widening participation agenda, Journal of Education Policy, 20(5), 615-630.

Keddie, N. (Ed.) (1973) Tinker, tailor... the myth of cultural deprivation (Harmondsworth, Penguin).

Kettley, N. (2007) The past, present and future of widening participation research, British Journal of Sociology of Education, 28(3), 333-347.

Kreber, C. (2005) Reflection on teaching and the scholarship of teaching, Higher Education, 50, 323-359.

Lampl, P. (2007, June 24) Kicking away the social ladder, The Sunday Times, p. 8. Lawson, N. (2006, August 10) Market logic turns a degree into a share certificate, The Guardian, p. 14.

McCormack, S. (2005, November 24) Old universities: big prizes for the poorest, The Independent, p. 4.

McFadden, M. (1995) 'Second-chance' education: settling old scores, Journal of Access Studies, 10(1), 40-59.

Mezirow, J. (1991) Transformative dimensions of adult learning (San Francisco, CA, Jossey-Bass).

Mezirow, J. (1995) Transformation theory of adult learning, in: M. R. Welton (Ed.) Defense of the lifeworld (New York, SUNY Press), 39-70.

Millar, P. \& Griffiths, S. (2007, January 28) University—who needs it?, The Sunday Times, p. 1. 
Murray, C. (1999) The underclass revisited (Washington, DC, American Enterprise Institute Books).

National Committee of Inquiry into Higher Education (1997) Higher education in the learning society (The Dearing Report) (Hayes, National Committee of Inquiry into Higher Education).

Nayak, A. (2003) 'Boyz to men': masculinities, schooling and labour transitions in de-industrial times, Educational Review, 55(2), 147-159.

Newby, H. (2004) Doing widening participation: social inequality and access to higher education. Colin Bell memorial lecture, given at the University of Bradford, 30 March. Available online at: www.hefce.ac.uk/news/events/2004/bell.doc (accessed 29 April 2006).

Parsons, T. (1951) The social system (New York, Free Press).

Quinn, J. (2003) Powerful subjects: are women really taking over the university (Stoke-on-Trent, Trentham).

Quinn, J. (2005a) Belonging in a learning community: the re-imagined university and imagined social capital, Studies in the Education of Adults, 37(1), 4-17.

Quinn, J. (2005b) Mass participation but no curriculum transformation, in: R. Jones \& D. Jary (Eds) Widening participation and university teaching and learning (Birmingham, C-SAP, Birmingham University).

Quinn, J., Thomas, L., Slack, K., Casey, L., Vigurs, K. \& Flynn, N. (2005a) Learners on their own terms: learning brokerage, mainstream transformation and social exclusion, Journal of Access Policy and Practice, 3(1), 21-44.

Quinn, J., Thomas, L., Slack, K., Casey, L., Thexton, W. \& Noble, J. (2005b) From life crisis to lifelong learning: rethinking working-class 'drop out' from higher education (York, Joseph Rowntree Foundation).

Randall, J. (2005, November 25) You can't brain up by dumbing down degrees, The Daily Telegraph, p. 5.

Reay, D., David, M. \& Ball, S. (2001a) Making a difference?: institutional habituses and higher education choice, Sociological Research Online, 5(4). Available online at: www.socresonline.org.uk/5/4/reay.html (accessed 25 August 2006).

Reay, D., David, M. \& Ball, S. (2005) Degrees of choice: class, race, gender and 
higher education (Stoke-on-Trent, Trentham Books).

Reay, D., Davies, J., David, M. \& Ball, S. (2001b) Choices of degree or degrees of choice? Class, 'race' and the higher education choice process, Sociology, 35(4), 855-874.

Saunders, P. (2005) The poverty wars (Sydney, University of New South Wales Press).

Schnelker, D. L. (2006) The student-as-bricoleur: making sense of research paradigms, Teaching and Teacher Education, 22, 42-57.

Slack, K. (2003) Whose aspirations are they anyway?, International Journal of Inclusive Education, 7(4), 325-335.

Sylvester, R. (2005, August 15) Mr Blair fears his city academies have not passed the test, The Daily Telegraph, p. 20.

Thomas, L. (2005) Higher education widening participation policy in England: transforming higher education or reinforcing elitism?, Ad-Lib, 29, Article 1. Available online at: www.cont-ed.cam.ac.uk/BOCE/ adlib29/article1.html (accessed 30 April 2006).

Thompson, J. (Ed.) (2000) Stretching the academy: the politics and practice of widening participation in higher education (Leicester, National Institute for Adult Continuing Education).

Universities and Colleges Admissions Service (2002) Paving the way: informing change in higher education progression partnerships with the voice of the under represented (Cheltenham, UCAS).

Universities UK (2002) Social class and participation in HE-from elitism to inclusion 2 (London, UUK).

Warmington, P. (2003) 'You need a qualification for everything these days.' The impact of work, welfare and disaffection upon the aspirations of access to higher education students, British Journal of Sociology of Education, 24(1), 95-108.

Williamson, H. (2004) The Milltown boys revisited (London, Berg).

Willis, P. (1977) Learning to labour (London, Saxon House).

Woodhead, C. (2007, May 20) Grammars sacrificed on the altar of compassionate Conservatism, The Sunday Times, p. 20.

Young, M. F. D. (Ed.) (1971) Knowledge and control (London, Collier-Macmillan). 
Young, M. F. D. (2005) Government intervention and the problem of knowledge in educational policy, lecture given at the University of Huddersfield, 26 May. 